Katarzyna Dworakowska

(Warszawa)

\title{
Idee Fryderyka Nietzschego w polskiej myśli o wychowaniu w latach 1883-1939
}

Celem niniejszego artykułu jest po pierwsze, przedstawienie zarysu recepcji myśli Nietzschego na przestrzeni dwóch epok, z nadzieją, że w przyszłości stanie się ona przedmiotem bardziej pogłębionych studiów. Po drugie, przynajmniej częściowe zaprezentowanie Nietzschego pedagoga, który wciąż pozostaje nieodkryty. To ostatnie zadanie jest o wiele ważniejsze nie tylko z uwagi na nieobecność Nietzschego w polskiej współczesnej myśli o wychowaniu, ale także ze względu na aktualność jego idei. Widoczną zwłaszcza w odczytaniach, które umieszczają filozofię autora Woli mocy na płaszczyźnie dyskursu kulturowego.

Pierwotnie tytuł artykułu miał brzmieć: „Recepcja myśli Fryderyka Nietzschego w polskiej pedagogice”. Pojęcie „recepcji”' jednak błędnie kierowałoby uwagę na bierne przyswajanie idei autora Narodzin tragedii, nie oddając twórczego wkładu interpretacyjnego. Ten rodzaj interakcji z tekstem nie był wprawdzie dominującym modusem odczytań, ukazał się jednak jako ważny i znaczący nie tylko z perspektywy badań historycznych, ale także współczesnego namysłu nad refleksją pedagogiczną Nietzschego. $\mathrm{Na}$ weryfikację pierwotnego tematu wpłynęły również problemy definicyjne dotyczące okresu sprzed instytucjonalizacji tego obszaru nauki, a także wynikające ze specyfiki tematu. Do głosu zostały dopuszczone także teksty, które wydają się nie mieć wiele wspólnego z pedagogiką. Okazało się jednak, że wespół z wypowiedziami nauki tworzą interesującą płaszczyznę rozważań o wychowaniu. Co więcej, to właśnie one nakreślają właściwą przestrzeń myśli Nietzschego. Wskazują kierunek, w jakim powinno podążać komentowanie jego myśli, jeśli chcemy wydobyć z nich coś więcej niż tylko krytykę ówczesnego systemu edukacji. Odkrycie to rodzi kolejne zapytanie, które w gruncie rzeczy jest pytaniem retorycznym: Czym jest pedagogika, jeśli nie głębokim namysłem nad istotą ludzką? A jako taka, powinna być ściśle związana z filozofią. Musi być z nią

\footnotetext{
${ }^{1} \mathrm{~W}$ tekście artykułu używam słowa „recepcja” zamiennie z takimi terminami, jak ,interpretacja” oraz „odczytanie”. Jest to spowodowane nie tylko wymogami stylistycznymi języka polskiego, ale również ograniczoną formułą tekstu, w której uwikłania semantyczne powyższych pojęć wprowadziłyby jedynie niepotrzebny zamęt.
} 
związana, jeżeli chce utrzymać swoją legitymizację do udzielania wyjaśnień dotyczących człowieka i jego odpowiedzialności w świecie. Tylko w takich kategoriach odczytywanie Nietzschego może mieć sens. W tym kryje się także odpowiedź na pytanie: Czy Nietzsche ma cokolwiek do zaoferowania współczesnej myśli pedagogicznej?

Twórczość Nietzschego dotarła do Polski bezpośrednio z Niemiec ${ }^{2}$, a jej polska recepcja należy do najwcześniejszych w skali światowej³ ${ }^{3}$ Datą otwierającą dialog ze spuścizną intelektualną autora Woli mocy jest (zgodnie z ustaleniami ${ }^{4}$ Marty Kopij) rok 1883, w którym ukazała się pierwsza wzmianka poświęcona Nietzschemu ${ }^{5}$. Do polskiej myśli pedagogicznej filozof wkradł się niejako kuchennymi drzwiami. Głównym tego powodem (choć na pewno nie jedynym) jest fakt, że problematyka jego pism nie leżała w obszarze zainteresowań ówczesnej myśli o wychowaniu, ulokowanej w naukowych kręgach pozytywizmu i skupiającej się na zadaniach praktycznych. Główny trzon recepcyjny stanowią nietzscheańskie tematy, które obecnie mogłyby być przedmiotem analiz pedagogiki kultury, a które w okresie Młodej Polski podjęła publicystyka ${ }^{6}$.

Pierwszym polskim tekstem omawiającym edukacyjny aspekt filozofii Nietzschego była książka Jerzego Kurnatowskiego Nietzsche. Studia i tłumaczenia, która ukazała się w 1903 r. Należy również dodać, że jest to jedyne dzieło okresu Młodej Polski, które wydobywa z twórczości niemieckiego myśliciela jej stricte pedagogiczne refleksje. Autor odczytuje nietzscheański ideał wychowawczy w duchu platońskim. Zdaniem Kurnatowskiego Nietzsche jest zdecydowanym ,zwolennikiem wychowania pozadomowego i to od najmłodszych lat"7. Rolę kluczową odgrywa postać wychowawcy, na którym spoczywa ciężar edukacyjny kształtowania społeczeństwa przyszłości. Jego zadaniem jest „ze swoim 'sumieniem intelektualnym' (poczuciem rzeczywistych zdolności i potrzeb

2 M. Kopij, Friedrich Nietzsche $w$ literaturze i publicystyce polskiej lat 1883-1918. Struktura recepcji, Poznań 2005, s. 20 n.

3 Jednym z prekursorów nietzscheanizmu w kraju i na świecie był Stanisław Przybyszewski, autor wydanej w 1892 r. Zur Psychologie des Individuums. I. Chopin und Nietzsche. (zob. M. Kopij, ibidem, s. 260).

4 Większość (jeśli nie wszyscy) badaczy podaje jako datę rozpoczynającą polską recepcję rok 1890, w którym na łamach „Prawdy” ukazało się omówienie fragmentu Umysłów współczesnych Georga Brandesa, poświęconego indywidualizmowi w filozofii Nietzschego (por. T. Weiss, Fryderyk Nietzsche w piśmiennictwie polskim lat 1890-1914, Wrocław-Kraków 1961, s. 5; Cz. Miłosz, Historia literatury polskiej do roku 1939, Kraków 1995, s. 375; B. Baran, Postnietzsche. Reaktywacja, Kraków 2003, s. 120).

5 Pierwsza wzmianka o Nietzschem pochodzi z pracy Leona Pinińskiego O operze nowoczesnej $i$ znaczeniu Ryszarda Wagnera oraz o Parsifalu Wagnera, Lwów 1883, s. 62, 64. W 1888 r. ukazał się artykuł Napoleona Hirschbanda (Cezary Jellenta) Apostot nicości (po latach stu) („Prawda” 1888, nr 8, s. 93). W roku następnym tekst Ladawy (najprawdopodobniej Alfred Nossig) Fryderyk Nietzsche, niemiec (sic!) filozofujacy młotem („Prawda” 1889, nr 38, s. 453 n.) Zob. M. Kopij, op.cit., s. 9 n.

${ }^{6}$ Wpływ (zapośredniczony zarówno w literaturze, jak i publicystyce) filozofii Nietzschego (,łowcy dusz nieostrożnych" jak nazywa go Alojzy Riehl w książce Fryderyk Nietzsche. Artysta i myśliciel, Warszawa: Wydawnictwo „Przeglądu Tygodniowego”, 1900, s.22 ) na kształtowanie postaw i światopoglądu młodego pokolenia wykracza poza temat niniejszego artykułu. Niemniej pozostaje zjawiskiem charakterystycznym dla recepcji myśli niemieckiego filozofa w okresie polskiego modernizmu oraz dwudziestolecia międzywojennego. Zobacz m.in.: B. Merwin, Nietzscheana, „Prawda” 1902, nr 32, s. 381; M. Straszewski, Fryderyk Nietzsche i jego znaczenie w ruchu umysłowym współczesnym, „Przewodnik Naukowy i Literacki” 1906, r. 34, s. 614 n.; Z. Kozubski, Fryderyk Nietzsche i jego etyka, Poznań: Księgarnia św. Wojciecha, 1924, s. 172.

7 J. Kurnatowski, Nietzsche. Studia i thumaczenia, Łódź: Rychliński i Wegner, 1903, s. 67. 


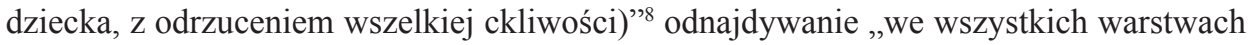
społeczeństwa "szlachetnego zmysłu władczej wiedzy"'. Z tego materiału ma on ,urabiać rządzącą arystokrację ducha” i z całą „,bezwzględnością, do której jest uprawniony przez wiedzę, charakter i doświadczenie, kierować dane dziecko, zależnie od jego indywidualności, na 'pana' lub 'niewolnika"'10.

Dominującym rodzajem odczytań myśli Nietzschego są jednak teksty, pojmujące zadania wychowawcze realizowane przez autora i jego dzieło, w szerokim kontekście oddziaływań społecznych i kulturowych. Wiktor Strusiński w artykule Nietzscheana z 1904 r. rozpatruje zagadnienie tworzenia rozumianego jako ujawnianie wartości ${ }^{11}$. Trudno powiedzieć, czy pojmuje on ten proces w ścisłych ramach czynności artystycznych, czy też jako element działań jednostki kształtującej swoją egzystencję z pasją i zaangażowaniem. Zdecydowanie umieszcza go jednak w orbicie oddziaływań społecznych. Sylwetka Nietzschego zaprezentowana jest jako postać proroka kultury i pedagoga ludzkości ${ }^{12}$, który w dziele zamknął całe swoje życie ${ }^{13}$, ofiarowując je drugiemu człowiekowi ${ }^{14}$. Jako ilustrację tych słów Strusiński podaje przykład Zaratustry, który wciąż na nowo podejmuje próby dotarcia do ludzi, a jego postępowanie motywowane jest miłością ku ludzkości, w niej odnajdując swój cel. W 1905 r. w „Chimerze” ukazał się artykuł Wacława Berenta Źródta i ujścia nietzscheanizmu, będący wstępem do Mortkowiczowskiej edycji dzieł zebranych Nietzschego. Berent, podobnie jak Strusiński, pedagogiczny aspekt myśli Nietzschego umieszcza w szerszej perspektywie. Wyraźnie zarysowującym się tłem jest tu jednak kryzys kultury i człowieczeństwa ${ }^{15}$. Autor Próchna ubolewa nad merkantylizacją ówczesnej edukacji oraz kondycją społeczeństwa, w którym rolę wychowawcy przejął dziennikarz: ,[...] wyłącznie zarobkowy duch dzisiejszego wykształcenia, działalność tłumiąca bakałarza i kierownicza dziennikarza: oto czynniki wychowawcze młodego pokolenia" ${ }^{16}$. Nie zadaje ono już sobie pytań: „kim jestem?” i „do czego zmierzam?”, a dostrzega jedynie utylitarny wymiar życia ${ }^{17}$. Szansę uzdrowienia widzi Berent w lekturze pism Nietzschego. Jego dzieła nazywa „,czynem twórczego wychowawcy”18, a samą działalność wychowawczą przywołuje jako życiowy cel autora Ecce homo ${ }^{19}$.

\footnotetext{
${ }^{8}$ Ibidem, s. 67.

${ }^{9}$ Ibidem.

${ }^{10}$ Ibidem, s. 67 n.

11 W. Strusiński, Nietzscheana, „Krytyka” 1904, t. 2, s. 105.

12 Ibidem, s. 106.

13 Ibidem, s. 276.

14 Ibidem, s. 105 n.

15 Berent podejmował ten wątek już wcześniej, m.in. w uwagach (uzupełniających dokonane przez niego tłumaczenie fragmentów tekstów Nietzschego) do Z psychologii sztuki („Chimera” 1902, z. 17, 18, s. 226 n.).

${ }^{16}$ W. Berent, Źródła i ujścia nietzscheanizmu, „Chimera” 1905, t. 9 , s. 121.

17 Ibidem.

18 Ibidem, s. $121 \mathrm{n}$.

19 Ibidem, s. 122.
} 
Artykuł Berenta wpisuje się w nurt recepcyjny, który w dziele Nietzschego dostrzegał lekarstwo na postępujący upadek cywilizacji ${ }^{20}$ „I właśnie wielkie kulturalne znaczenie filozofii Nietzschego polega na jej wyzwalającym charakterze"21 - odnotowywał Władysław Spasowski. Twórczość myśliciela w swojej warstwie krytycznej oraz projektach odnowy znajdywała szeroki oddźwięk w epoce, która zapytywała o swoją tożsamość i kształt przyszłości. Ponadto sytuacja polityczna ziem polskich wydobywała dodatkowe znaczenia tych postulatów, wpisując je w potrzebę zredefiniowania pojęcia patriotyzmu oraz dążenie do odmiennie prowadzonego dialogu z przeszłością 22 .

Interpretatorzy powoływali się przede wszystkim na Niewczesne rozważania oraz Tako rzecze Zaratustra, czytane w oryginałach. Podpisywali się pod atakiem na ówczesny wzorzec człowieka; biernego, odtwórczego ${ }^{23}$, o ograniczonych horyzontach intelektualnych ${ }^{24}$, skupionego jedynie na własnej przyjemności ${ }^{25}$. Zgadzali się z krytyką czasów, w których „każdy pismak z cynizmem rozprawia się z najwyższymi zagadnieniami życia"26. W dziełach Nietzschego dostrzegali również szansę nowego spojrzenia na kulturę, która „może być jeszcze czymś innym, niż dekoracją życia, to jest czymś innym, niż maską i osłoną"27. Ich wartość uzdrawiającą widzieli nie tylko we wskazaniu wad i błędów, w tym tych specyficznie polskich, takich jak kunktatorstwo czy hipokryzja ${ }^{28}$, ale także w wezwaniu do aktywności. „Dla ludzi i społeczeństw, pozbawionych z przyczyn zewnętrznych woli, energii, pewności siebie, zaufania w przyszłość, jest Nietzsche pobudką i łaźnią uzdrawiającą ducha"29.

Ciekawy, z punktu widzenia myśli o wychowaniu, jest głos Walerego Gostomskiego. Nie szczędzi on filozofii Nietzschego uwag krytycznych (zwłaszcza za jej antychrześcijański wydźwięk ${ }^{30}$ ), ale jednocześnie dostrzega w niej głęboką troskę o los istoty ludzkiej pogrążonej w kryzysie wartości. „Ten kult ludzi wyższych, to uznanie w nich celu i kresu całej kultury ludzkiej, jest uznaniem istoty człowieczeństwa w żywym człowieku, nie w oderwanych systemach, nie w bezdusznych instytucjach, nie w martwych formułach, które za dni naszych coraz bardziej zdają się pochłaniać całą siłę żywą naszego rozwoju kulturalnego"31.

${ }^{20}$ Istniał także nurt odwrotny postrzegający twórczość Nietzschego nie jako antidotum a przejaw dokonującego się upadku. Zob. T. Weiss, Fryderyk Nietzsche w piśmiennictwie..., rozdział: „Przeciwnicy Nietzschego w Polsce".

21 W. Spasowski, Filozofia Nietzschego, „Ogniwo” 1904, nr 52, s. 1227.

22 Por. Programy i dyskusje literackie okresu Młodej Polski, oprac. M. Podraza-Kwiatkowska, Wrocław-Warszawa-Kraków: Zakład Narodowy im. Ossolińskich, 2000, s. XIV.

23 S. Garfein, Fryderyk Nietzsche. Studium filozoficzne, „Ateneum” 1893, t. 2, s. 110 nn.

24 W. Spasowski, Filozofia Nietzschego, s. 1227.

25 W. Gostomski, Nietzsche i Tolstoj, 272.

26 S. Pieńkowski, Fryderyk Nietzsche, „Głos” 1900, nr 38, s. 604.

27 S. Garfein, Fryderyk Nietzsche, s. 113.

28 W. Rzymowski, Polska edycja dzieł Fryderyka Nietzschego, „Prawda”, 1911, nr 33, s. 12.

29 S. Pieńkowski, Fryderyk Nietzsche, ,Głos” 1900, nr 37, s. 586.

${ }^{30}$ Zob. W. Gostomski, Nietzsche jako przedstawiciel antychrześcijańskiego humanitaryzmu, „Przegląd Powszechny" 1902, t. LXXVI.

31 W. Gostomski, Tragedia myśliciela..., s. 495. 
Powyższe odczytania pism Nietzschego pozwalają naświetlić głębszy sens napiętnowanej przez filozofa kategorii Bildungsphilister, wykraczającej daleko poza krytykę ówczesnego modelu kształcenia, czy naganę udzieloną warstwie mieszczańskiej. W polskiej tradycji translacyjnej, w zasadzie bez wyjątków, pojęcie Bildung funkcjonuje jako „wykształcenie”. Takie pojmowanie usuwa w cień pozostałe sensy tego terminu, uwagę kierując na formalne zdobywanie wiedzy. Werner Jaeger umieszcza kategorię Bildung między takimi obszarami semantycznymi, jak „kultura”, „wychowanie” oraz „kształtowanie" (do określonego wzorca) ${ }^{32}$. Idąc za tą wskazówką można zatem przyjąć, że nietzscheańskie Bildung to wychowanie rozumiane jako dialektyczne uczestnictwo w kulturze, wraz z jego normatywnymi rozstrzygnięciami. Tezę tę zdaje się potwierdzać myśl Huberta Orłowskiego, który stwierdza: „,Bildung to rodzaj kapitału kulturowego, a nawet symbolicznego (w rozumieniu Pierre’a Bourideu), a więc zespół walorów wysoko cenionych i pożądanych w oczach mieszczaństwa"33. Formacji, która przejmując kulturową dominację, narzucała swoje rozumienie świata wraz z prawomocnymi kategoriami ${ }^{34}$ jego postrzegania ${ }^{35}$. Problem, który dostrzegł Nietzsche i jego komentatorzy nie leżał zatem w wartościach, którym hołdowała określona grupa społeczna, ale w wartościach roszczących sobie prawo do powszechności. Walery Gostomski stwierdza, że chociaż „duch filisterstwa” był obecny w historii od dawna (m.in. pod postacią niemieckiego Spiesbürger'a czy francuskiego rentier ' $\left.a^{36}\right)$, to jednak ,za dni naszych, wraz z bezwzględną przewagą jednostronnej, materialnej kultury, ponad wszelką miarę się rozpanoszył" ${ }^{\prime 3}$. W konsekwencji, to co było domeną jednej warstwy społecznej, przybrało postać uniwersalnego żądania, a wzorzec człowieka przeniesiony został z ,mieszczańskich poziomów na wyżyny cywilizacyjne" 38 . Przyjęcie takiego punktu widzenia pozwala na translokację Nietzscheańskich rozważań nad „wykształconym filistrem”, czy też raczej „filistrem kulturalnym”, z obszaru dyskusji o gustach na płaszczyznę dyskursu cywilizacyjnego, w którym naczelnym zagadnieniem staje się człowieczeństwo oraz jego materialne i niematerialne przejawy.

W 1906 r. w „Przeglądzie Naukowym i Literackim” ukazał się artykuł Maurycego Straszewskiego Fryderyk Nietzsche i jego znaczenie w ruchu umysłowym współczesnym stanowiący swoiste résumé dotychczasowej obecności filozofa w polskim życiu intelektualnym. Przyznaje on Nietzschemu rolę kształtującą w obrębie literatury i postaw młodego pokolenia. Stwierdza równocześnie jego znikomą obecność w zakresie nauki. „W ruchu ściśle naukowym i filozoficznym wpływ Nietzschego u nas nie wydał jeszcze zbyt pokaźnych owoców [...]. Wpływu jego na poważną pracę naukową i filozoficzną, ja

\footnotetext{
${ }^{32}$ W. Jaeger, Paideia, Warszawa 2000, s. 37 n.

${ }^{33}$ Cz. Karolak, W. Kunicki, H. Orłowski, Dzieje kultury niemieckiej, Warszawa 2006, s. 338.

${ }^{34}$ Warto w tym miejscu przypomnieć także o kształtującej się od XVIII w. „,mieszczańskiej sferze publicznej" (bürgerliche Offfentlichkeit), o której pisze Jürgen Habermas w książce Strukturalne przeobrażenia sfery publicznej.

35 Ibidem, s. $338 \mathrm{nn}$.

36 W. Gostomski, Nietzsche i Totstoj, „Przegląd Polski”, 1905, kw. III, s. 258.

${ }^{37}$ Ibidem, s. 272.

${ }_{38}$ W. Gostomski, Tragedia myśliciela (Fryderyk Nietzsche i jego ideał humanitarny), „Biblioteka Warszawska"1906, t. 1, s. 486 n.
} 
bym się nie obawiał, mógłby on nawet niejednego wyleczyć z różnych naukowych przesądów, mógłby rozbudzić krytycyzm wszechstronny, a w myśleniu filozoficznym podniecić do sumienności przede wszystkim wobec siebie samego" ${ }^{39}$. Rok później w „Krytyce” ukazała się recenzja niejakiego Adama R. dotycząca zbiorowej edycji dzieł Nietzschego. Jej autor zwiastuje nowy etap w recepcji filozofa. „Nietzsche - linoskok przyjęty oklaskiem i krzykiem tłumu - umarł; ale Nietzsche orzeł i wąż pozostał, i rozpoczął się zachód Zaratustry tam, gdzie był powinien - w nauce. [...] Należy więc właśnie teraz Nietzschego zacząć czytać i rozumieć"40. Opinie te wydają się ważne ze względu na zasygnalizowanie potrzeby przesunięcia akcentów recepcyjnych i otworzenia myślom Nietzschego nowych, dotąd niewykorzystanych wejść.

Pedagogiczny trop nietzscheanizmu urywa się w tym miejscu, aby pojawić się w zmienionej już formie w latach dwudziestych minionego wieku. Idee twórcy Narodzin tragedii wyraźnie zostają umiejscowione w orbicie rozważań o wychowaniu ${ }^{41}$. Autorzy rzadko jednak sięgają do źródła traktowanego jako samoistna wartość, która podlega refleksji i krytycznemu namysłowi. Najczęściej jedynie przywołują postać Nietzschego jako inspiratora prądów intelektualnych bądź konkretnych myślicieli, którzy znaleźli się w sferze ich zainteresowań. Z dzieł filozofa wydobyto przede wszystkim hasła ,indywidualizmu”, „krytyki tradycyjnego systemu nauczania” oraz ,irracjonalizmu”.

W 1926 r. Antoni Bolesław Dobrowolski, obejmując katedrę pedagogiki na Wolnej Wszechnicy Polskiej wygłosił referat inauguracyjny. W wykładzie tym (zatytułowanym „Rudolf Maria Holzapfel ${ }^{42}$ i podstawy naukowe wychowania uczuć”) Nietzsche został ukazany jako jeden z inspiratorów analizy uczuć dokonanej przez Holzapfla ${ }^{43}$. Do czynników wytyczających kierunek prac Holzapfla Dobrowolski zalicza m.in. zarówno Nietzscheańską introspektywną metodę badania zjawisk psychicznych, jak i zakwestionowanie ich moralnego naznaczenia, otwierające drogę analizie naukowej. „Nietzsche nauczył Holzapfla odważnie nurkować w przepaście duszy ludzkiej i drapać się na jej wyżyny, ścierać z ludzkich popędów i uczuć barwy ,dobrego' i ,złego’ i nowym, niezmąconym tradycją, spoglądać na nie okiem, wżywać się w najważniejszy świat uczuć: w życie uczuciowe twórców, i do ,najświętszych' uczuć nie bać się przystąpić ze skalpelem w ręku"44. Powstałe na tym gruncie „wychowanie uczuć"45 jest wciąż jeszcze nieodkrytym „całości wychowania kamieniem węgielnym, jest częścią wychowania

39 M. Straszewski, Fryderyk Nietzsche..., s. 614.

40 R. Adam, Dzieła Fryderyka Nietzschego (recenzja), „Krytyka” 1907, t. 1, s. 107 n.

${ }^{41}$ Nieuzasadnione jest jednak zaliczanie Nietzschego do grona wychowawców klasyków, jak uczynił to Grzegorz Kowal w swojej pracy Friedrich Nietzsche w publicystyce i literaturze polskiej lat 1919-1939, Warszawa 2005, s. 158 przyp. 641.

${ }^{42}$ Holzapfel Rudolf Maria (1874-1930): psychologiczno-filozoficzny pisarz. Stworzył system mający łączyć wszystkie aspekty życia ludzkiego w harmonijną jedność, łączyć elementy kultury z naturą i religią. Na podstawie: Neue Deutsche Biographie, Berlin 1972, t. 9, s. 569 n.

${ }^{43}$ Na wpływ filozofii Nietzschego na myśl Holzapfla zwracał uwagę także Strusiński patrz: W. Strusiński, Nietzscheana, przypis na s. 272.

44 A. B. Dobrowolski, Rudolf Maria Holzapfel i podstawy naukowe wychowania uczuć, Warszawa (odbitka z miesięcznika „Droga” nr 1-3, 1927), 1927, s. 11.

45 Ibidem, s. 3. 
centralną"46. Dobrowolski wymienia również inne wątki zaczerpnięte z filozofii Nietzschego i rozwijane w systemie Holzapfla. „Idzie za Nietzschem, w tym, że podkreśla niesłychaną ważność uwzględniania różnic duchowych między ludźmi, pielęgnowania tego, co stanowi o ich indywidualności, otoczenia sympatią osobliwości duchowych, ukochania wyjątków - geniuszów. Idzie za Nietzschem i w tym, że za najwyższy cel, najwyższy ideał daje ludzkości naukowo obstawiony równoważnik Nadczłowieka, mianowicie maksymalny rozwój jednostek - rozwój duchowy integralny zarówno moralny, jak estetyczny, umysłowy i religijny, ideał mający być zharmonizowaniem wszystkich tych różnych ideałów: ,Wszechideał" "47. Dobrowolski odnajduje również myśl Nietzschego na gruncie poszukiwań wartości, mogących stanowić drogowskaz dla przyszłych pokoleń. „Dzisiejszy świat duchowy, świat celów, świat ideałów, to chaos. [...] Inteligent dzisiejszy, tego miana godny, niech omija starannie ów rynek wartości ${ }^{48}$. I niech tam patrzy, gdzie naprawdę nowe wartości się rodzą w pocie czoła twórców prawdziwych: nowe gwiazdy przewodnie Człowieka. W tej [...] pracy twórczej trzy widzimy etapy - trzy jak gdyby epoki nowej myśli religijnej, [...]. Te trzy etapy - to Guyau $^{49}$, Nietzsche i Holzapfel'"50.

W okresie Dwudziestolecia dzieło autora Jutrzenki pojawiło się w encyklopediach wychowawczych. Przywołano w nich jego (pominięte w okresie modernizmu i zapomniane obecnie) dzieła pedagogiczne sensu stricto. Podręczna encyklopedia pedagogiczna w opracowaniu Feliksa Kierskiego z 1923 r., dzieląc twórczość Nietzschego na „trzy epoki”, podaje: „Pedagogiką interesuje się N. w I epoce (1866-1874). Na ten czas przypada jego praktyczna działalność pedagogiczna i prace specjalnie pedagog.: O przyszłości naszych zakładów wychowawczych (Übre die Zukunft unsrer Bildungsanstalten, 1871/2), My filologowie (Wir Philologen, 1875, niedokończona). [...] filistrowi w wykształceniu (Bildungsphilister) przeciwstawia geniusz artystyczny, na usługach którego winno stać wychowanie" 51 . Nietzsche przedstawiony jest jako krytyk klasycznego kierunku wychowania oraz przedstawiciel indywidualizmu w pedagogice ${ }^{52}$. Podręczny leksykon pedagogiczny Kazimierza Królińskiego z 1935 r. pod hasłem „Nietzsche” podaje: „filozof niemiecki, zajmował się także sprawami pedagogiczn." ${ }_{33}$, powtarzając następnie, w skróconej formie, informacje z Kierskiego.

Podobny obraz twórczości Nietzschego odmalowuje Ludwik Chmaj w wydanych w 1938 r. Kierunkach i prądach pedagogiki współczesnej. W rozdziale poświęconym

46 Ibidem.

47 Ibidem, s. 16.

48 Warte odnotowania jest, że w tym i następnych akapitach Dobrowolski przejmuje zarówno metaforykę, jak i styl Nietzschego.

49 Guyau Jean Marie (1854-1888): filozof i socjolog francuski. Uważał, że celem wychowania powinien być harmonijny rozwój intelektualny moralny i obywatelski wychowanka. Za: K. Króliński, Podręczny leksykon pedagogiczny, Poznań 1935, s. 60.

${ }^{50}$ A. B. Dobrowolski Antoni Bolesław, Rudolf Maria..., s. 15.

${ }^{51}$ F. Kierski Feliks, Podręczna encyklopedia pedagogiczna, Lwów-Warszawa 1923, s. 324 n.

52 Ibidem.

${ }^{53}$ K. Króliński, Podręczny leksykon pedagogiczny, op.cit., s. 169. 
edukacji artystycznej autor Niewczesnych rozważań przedstawiony został jako jeden ze sprzymierzeńców (przez wykazanie irracjonalizmu życia oraz poszukiwanie źródeł pewności nie w rozumie, ale uczuciu i intuicji) niemieckiego ruchu krytykującego intelektualizm szkoły tradycyjnej ${ }^{54}$. Chmaj przywołuje Narodziny tragedii oraz Niewczesne rozważania, w których to Nietzsche wystąpił przeciw ,jednostronnej uczoności (,wykształconości’), przeciwko błędnej pedagogice, uważającej ,człowieka wykształconego' za konieczny i rozumny warunek wszelkiego dalszego wychowania i użytecznemu człowiekowi nauki, wykształconemu filistrowi, przeciwstawił ideał świętego i artysty, przewadze historii - plastyczną moc sztuki" "55. Wzmianka o autorze Wiedzy radosnej pojawia się również (w rozdziale „Psychologia indywidualna”) przy nazwisku Alfreda Adlera ${ }^{56}$. „Powołując się na Pestalozzi ego ${ }^{57}$, który wykazał, iż matka służy dziecku w jego odnoszeniu się do innych ludzi za gwiazdę przewodnią oraz na Nietzschego, według którego każdy na wzór swej matki tworzy sobie obraz idealny swojej ukochanej, podnosi Adler również, iż matka jest dla dziecka najsilniejszym i najważniejszym przeżyciem [...]"58. Nazwisko Nietzschego autor zestawia również z ,,pedagogiką socjologiczną” Paula Bergemanna $^{59}$, który to zapożyczył od Zaratustry „etykę siły” i „religię życia” i uczynił je „najwyższym wymaganiem wychowawczym"60 Omawiając idee Friedricha Wilhelma Foerstera $^{61}$, Chmaj pisze z kolei, że czerpie on ${ }^{62}$,pełną dłonią z dzieł wielkiego znawcy chorej duszy ludzkiej, Fryderyka Nietzschego"63.

Również w publicystycznych kręgach pedagogiki idee autora Zmierzchu bożyszcz pojawiały się w analizach, których punktem odniesienia była genealogia ówczesnych nurtów umysłowych. W studiach tych Nietzsche postrzegany był przede wszystkim jako orędownik indywidualizmu. „W ostatnich czasach wprowadzono w pedagogice prawdziwy „kult indywidualności” czyli osobowości, do czego przede wszystkim przy-

${ }^{54}$ L. Chmaj, Kierunki i prądy pedagogiki współczesnej, Warszawa-Wilno 1938, s. 144 n.

55 Ibidem, s. 145.

${ }^{56}$ Adler Alfred (1870-1937): austriacki psychiatra, psycholog oraz pedagog. Początkowo związany był z doktryną Freuda, następnie stworzył własną szkołę tzw. psychologii indywidualnej. Twierdził, że głównym zadaniem wychowania jest harmonizowanie rozwoju jednostki pogrążonej w wewnętrznym konflikcie. Na podstawie: W. Okoń, Nowy stownik pedagogiczny, Warszawa 1998, s. 10.

57 Pestalozzi Johann Heinrich (1746-1827): szwajcarski pisarz i pedagog. Twórca oryginalnego systemu dydaktycznego wypróbowanego w prowadzonych przez niego szkołach i zakładach wychowawczych. Łączył wychowanie umysłowe z praktycznym przygotowaniem do życia, doceniając jednocześnie wychowanie moralno-religijne oraz fizyczne. Za: W. Okoń, op.cit., s. 291.

58 L. Chmaj, op.cit., s. 301.

59 Bergemann Paul (1862-1946): pedagog, swój system opierał na teorii biologiczno-pozytywistycznej, wysuwając na plan pierwszy kształtujący czynnik środowiskowy. Na podstawie: Neue Deutsche..., 1955, t. 2, s. 78 .

${ }^{60}$ Ibidem, s. 358.

${ }^{61}$ Foerster Friedrich Wilhelm (1869-1966): niemiecki pedagog, przedstawiciel pedagogiki chrześcijańskiej. Kładł nacisk na rozwój moralny odbywający się przez pełne wykorzystanie materiału nauczania, jak i w toku działalności społecznej. Na podstawie: W. Okoń, op.cit., s. 101.

${ }^{62}$ Myśl F. W. Foerstera była w Polsce nośnikiem Nietzscheańskich idei pedagogicznych. Zobacz m.in.: F. W. Foerster, Wychowanie i samowychowanie, Lwów: Księgarnia Wydawnicza L. Igel, 1934, przedmowa: Jan Kuchta

63 L. Chmaj, op.cit., s. 694. 
czynili się: Nietzsche, Ellen Key ${ }^{64}$ i Gurlitt ${ }^{65}{ }^{\prime 66}$ - odnotowywał Paweł Tochowicz. Podobne spostrzeżenia ma Józef Pastuszka. Badając wpływ filozofii Nietzschego na pedagogikę stwierdza, że silnie oddziaływała ona na kształt psychologii indywidualnej Alfreda Adlera, „która instynkt mocy uważa, obok popędu społecznego, za dążenie podstawowe,

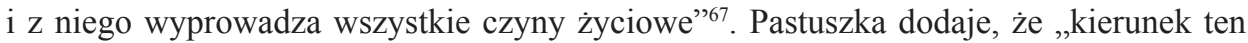
jest dziś szeroko stosowany w szkolnictwie austriackim (w Wiedniu) i uważany za oficjalną metodę wychowawczą socjalizmu"68. Przywołuje także stanowisko E. Przywary, który nietzscheańską genezę przypisuje również ruchowi młodzieży niemieckiej - Jugendbewegung ${ }^{69}$. „Jest on reakcją przeciwko przesadnemu intelektualizmowi, oderwaniu od przyrody i sztucznym warunkom życia wielkomiejskiego. Głosi nawrót do natury, pielęgnuje naturalne instynkty, wyrabia samowystarczalność i duży nacisk kładzie na rozwój sportu" ${ }^{\prime 70}$. Nietzsche pojawia się też jako inspirator „prądów irracjonalistycznych”71 epoki oraz prekursor filozofii życia, która „,cechuje przede wszystkim wrogie stanowisko względem intelektualizmu, naturalizmu, mechanizmu i determinizmu - podkreślanie irracjonalnych czynników w świecie, zwłaszcza zaś w duszy człowieka, których przewaga nadaje rzeczywistości wewnętrznej charakter wolności i dynamizmu, woluntaryzmu i indywidualizmu"72.

Naturalną konsekwencją postrzegania Nietzschego jako czołowego adherenta indywidualizmu było włączenie go w spór dotyczący relacji pomiędzy jednostką a społeczeństwem. Interesujący w tej dyskusji jest głos Tochowicza, który w indywidualistycznej filozofii Nietzschego dostrzega nie zagrożenie, lecz szansę dla współczesnego człowieka. W artykule Pedagogika radykalno-społeczna, rozważając kierunek rozwoju pedagogiki społecznej, Tochowicz sygnalizuje niebezpieczeństwo wynikające z jej radykalnych form, uderzających w jednostkowość. „Dynamika życia społecznego spoczywa zasadniczo w osobowości. Jeśli człowiek nie odrodzi się wewnętrznie, to nie można się rozumnie spodziewać odrodzenia społecznego"73. Indywidualizm Nietzschego, jego niechęć do zastanych norm społecznych Tochowicz przyjmuje zatem jako drogowskazy wychowawcze. „Dążność człowieka do uznania, do stosowania się, do powodzenia, do pochwały; [...] skłonność do popisywania się, ambicja, próżność; [...] wpływ masy

${ }^{64}$ Key Ellen (1849-1926): szwedzka nauczycielka i pisarka, walcząca o pokój i prawa kobiet. Zwolenniczka skrajnego indywidualizmu w wychowaniu. Za: W. Okoń, op. cit., s. 161.

65 Gurlitt Georg Remi (1855-1931): przedstawiciel pedagogiki reformy. Zwolennik skrajnego indywidualizmu. Na podstawie: Neue Deutsche..., 1966, t. 7, s. 330.

${ }^{66}$ P. Tochowicz, Fryderyk Wilhelm Foerster, „Ateneum Kapłańskie” 1938, t. 41, z. 1, s. 53.

67 J. Pastuszka, Filozofia Nietzschego i jej wpływ na współczesna umysłowość, „Ateneum Kapłańskie” 1933, t. 31 , z. 4 , s. 329 .

68 Ibidem.

${ }^{69}$ Nie udało się odnaleźć żadnych informacji na temat tego ruchu.

70 Ibidem.

71 J. Pastuszka, Współczesne prądy filozoficzne, „Kultura i Wychowanie” 1938, z. 3, s. 204.

72 G. Landau, Wplyw ,filozofii życia” na współczesny ruch pedagogiczny w: Polskie badania nad myśla pedagogiczna w latach 1900-1939. Parerga, oprac. S. Sztobryn, M. Świtka, Gdańsk 2006, s. 108 nn. Pierwodruk: „Chowanna” 1929, t. 1, s. 233 nn.

73 P. Tochowicz, Pedagogika radykalno-społeczna, „Ateneum Kapłańskie” 1936, t. 37, z. 3, s. 260. 
i środowiska, czar i urok mody, opinii publicznej, [...] słowem owczy pęd ludzi, brak samodzielności i prawo najmniejszego wysiłku - oto niebezpieczeństwa instynktu społecznego. ,Gemeinschaft macht gemein' powiedział Nietzsche, a zdanie to, jeśli jest dobrze pojęte, wyraża głęboką prawdę chrześcijańską" "74. Obronić się przed tymi zagrożeniami (tylko wtedy, zdaniem autora, można właściwie służyć społeczeństwu) może tylko jednostka, która potrafi zdobyć „wolność i autonomię osobistą, panowanie nad sobą samym"75.

Do osobnej kategorii należy zaliczyć broszurę Stanisława Bessera Bohaterowie myśli. Nietzsche $i$ Weininger ${ }^{76}$ oraz artykuł Mariana Wachowskiego Wspomnienia z pism pedagogicznych Nietzschego $i$ Grundtviga ${ }^{77}$. Pierwszy tekst jest swego rodzaju poetyckim hołdem dla tytułowych postaci i nie wnosi wiele do zrozumienia twórczości autora Zaratustry. W krzywdzącym dla Nietzschego zestawieniu z Otto Weiningerem, obaj zostali przedstawieni jako wychowawcy „człowieka, narodów, ludzkości”78, którzy „prawdę myśli swoich dowiedli przebiegiem i końcem swojego żywota"79. Artykuł Wachowskiego natomiast do chwili obecnej pozostaje jedynym polskim omówieniem cyklu wykładów ${ }^{80}$ autora Wiedzy radosnej, pochodzących z okresu jego działalności na uniwersytecie w Bazylei. Wachowski zestawia poglądy Nietzschego i Grundtviga, dwóch reformatorów wychowania ${ }^{81}$, nieprzychylnych wobec ówczesnego sytemu edukacji. Stanowisko Nietzschego, koncentruje się wokół krytyki gimnazjum klasycznego. Jest to jednak atak na program tych szkół, zdominowany przez filologię klasyczną, kosztem języka ojczystego, nie zaś na samą ich ideę. Zdaniem Nietzschego szkoła średnia nie wywiązuje się ze swego celu, produkując urzędników zamiast twórców kultury. Tymczasem to wychowanie tych drugich powinno być naczelnym zadaniem społeczeństwa. Stąd też postulat elitaryzmu edukacyjnego, obejmujący także oświatę pozaszkolną. Wachowski nie ogranicza się jednak tylko do opisu poglądów pedagogicznych myśliciela. Zadaje także pytanie o ich aktualność, dając na nie odpowiedź twierdzącą. Swoją ponadczasowość zawdzięczają przede wszystkim temu, że Nietzsche „,nie tracił z oczu całokształtu kultury i zdawał sobie sprawę, że obok wpływów wychowawczych człowiek podlega jeszcze innym wpływom kulturowym. Dostrzegał w pełni [...] tragizm ówczesnej, a więc również współczesnej nam kultury" ${ }^{\$ 2}$. Zdaniem autora artykułu elitarny ideał kształcenia proponowany przez Nietzschego jest formą obrony przed merkantylizacją i umasowie-

74 P. Tochowicz, Pedagogika radykalno-społeczna, s. 262.

75 Ibidem.

76 Weiniger Otto (1880-1903): austriacki filozof, jego książka Płeć i charakter była manifestem mizoginizmu i antysemityzmu. Na podstawie: http://en.wikipedia.org/wiki/Otto_Weininger

77 Grundtvig Nikolai Frederik Severin (1783-1872): duński pedagog, poeta, polityk i kaznodzieja. Propagował idee uniwersytetów ludowych w celu odrodzenia kultury narodowej. Za: W. Okoń, op.cit., s. 115.

78 S. Besser, Bohaterowie myśli. Nietzsche $i$ Weininger, Warszawa 1929, s. 6.

79 Ibidem, s. 5.

${ }^{80}$ Wydanych pośmiertnie pod wspólnym tytułem Über die Zukunft unserer Bildungsanstalten.

${ }^{81}$ M. Wachowski, Wspomnienia z pism pedagogicznych Nietzschego i Grundtviga, „Praca Oświatowa” 1936, nr 9, s. 513.

${ }^{82}$ Ibidem, s. 518. 
niem kultury. „Swobodnie hasająca w gazetach plebejska poufałość wobec wytworów kultury, wzrastająca produkcja tandety, napełniały Nietzschego przerażeniem i skłoniły go do szukania sposobów przeciwdziałania barbarzyństwu w wychowaniu arystokratycznym"83. Według Wachowskiego współczesna pedagogika powinna skorzystać z wzorca nietzscheańskiego. Odczytać jego elitaryzm wychowawczy jako postulat polegający „na tym, że jednostka rozprawia się z wulgaryzmem współczesnej kultury, nie idzie z prądem czasu, [...] chce być skupiona i krytyczna [...] stoi na uboczu i tu przygotowuje w sobie i w swym otoczeniu podstawy odrodzenia kulturalnego" 84 .

Odczytywanie filozofii Nietzschego zostało zakończone w 1939 r. Nazistowskie konotacje, w które wpisano jego dzieła, na długie lata przerwały ten proces. Nie tylko na obszarze rozważań o wychowaniu, ale także filozofii. I o ile do tej drugiej tryumfalnie powrócił ${ }^{85}$, o tyle w przypadku polskiej pedagogiki - pozostał na wygnaniu ${ }^{86}$. Spostrzeżeniem, które narzuca się przy analizie recepcyjnej jest jednak nie tyle zaniechanie przenoszenia Nietzscheańskich idei na grunt edukacyjny, ile znikome wykorzystanie zawartego w nich potencjału. Interpretacje nieoperujące hasłami, traktujące dzieło jako odrębną wartość, która niesie w sobie przesłanie - są rzadkością. Tymczasem Nietzsche ma nam pedagogom wciąż wiele do zaoferowania tak przez akceptację jego myśli, jak i polemikę z nimi. Przestrzeń interpretacyjna nakreślona przed ponad stu laty, dzięki ujawnieniu perspektyw i zagrożeń jest szansą na ponowne podjęcie dialogu z twórczością Nietzschego. Tym bardziej, że w żadnym momencie jego trwania nie możemy go uznać za zakończony.

\section{F. Nietzsche's ideas in Polish educational thought between 1883 and 1939}

\section{Summary}

The article discusses outstanding interpretations of the works by F. Nietzsche as represented in Polish educational thought during the "Young Poland" period and the following interwar period. The study aims at elucidating the pedagogical dimensions of Nietsche's idea in the interpretation of the two periods and at identifying the space within which the concept of the author of Thus spake Zarathustra still remains topical and current.

The section devoted to the "Young Poland" period includes an analysis of Jan Kurnatowski's book Nietsche. Studia i thumaczenia [Nietzsche. Studies and translations], the one and only work of the period that extracts from the output of the German thinker its strictly pedagogical reflections. The next issue to be presented is a discussion on the journalistic writing that was engaged in

83 Ibidem, s. 519.

84 Ibidem, s. 520.

${ }^{85}$ W latach siedemdziesiątych zaczęły ukazywać się teksty wolne od rozważań na temat Nietzschego ideologa nazistów, a poświęcone analizie filozoficznej jego dzieł. Por.: W. Mackiewicz, Myśl Fryderyka Nietzschego w Polsce w latach 1947-1997. Studium historyczno-krytyczne, Warszawa 1999, s. 152.

86 Jednym z nielicznych, którzy dostrzegają ważność wkładu filozofii Nietzschego w namysł nad edukacją jest Józef Pietrzak. Zob.: m.in. J. Pietrzak, Nietzscheańska koncepcja wychowania, Słupsk 1997. Zob. także: K. Dworakowska, Zaratustra jako wychowawca, „Kwartalnik Pedagogiczny” 2008, nr 2. 
Nietzschean themes that would be of interest to the present-day pedagogy of culture. Interpretation trends that aimed to discover a universal remedy for the crisis in culture and humanity in the works of the author of Untimely Meditations turned out to be dominant at the time. An approach to the interpretation of Nietzsche's thought in a wide context of social and cultural interactions made it possible to conclude that the category of Bildungsphilister, castigated by the philosopher, reaches much further beyond just criticism of the contemporary model of education due to the tenability of the notion of Bildumg as the accumulation of cultural capital as it was viewed by Pierre Bourideu. In conclusion of the discussion on the modernist period, the author presents postulations that indicate a need for a shift in the reception emphasis towards directions hitherto unexplored.

The section devoted to the interwar period presents the interpretation of the pedagogical thought of Nietzsche presented at the inauguration lecture (on the occasion of Antoni Bolesław Dobrowolski's acceptance of the chair of pedagogy at Wolna Wszechnica Polska [Free Polish University]) delivered by the professor. The presentation is followed by a discussion on the different approaches presented in various pedagogical encyclopaedias and in Ludwik Chamaj's Kieruki i prądy pedagogiki współczesnej [Trends and directions in modern pedagogy]. The latter approaches present Nietzsche as an instigator and a prime mover in contemporary intellectual currents and trends and discuss his influence upon individual philosophers, extracting from his philosophical output the notions of "individualism", "criticism of the traditional educational system" and "irrationalism". The journalistic writings under investigation fit well into this particular interpretative trend. The discussion on the interwar period is complemented with a reference to a booklet written by Stanisław Besser and entitled: Bohaterowie myśli. Nietsche i Weininger [Heroes of Thought. Nietzsche and Weininger] and an analysis of the article written by Marian Wachowski Wspomnienia z pism pedagogicznych Nietzschego i Grundtviga [Pedagogical reflections in the writings of Nietzsche and Grundtvig], being the only Polish contribution to the discussion on the series of lectures by Nietzsche Ueber die Zukunft unserer Bildungsanstalten. 